\title{
FISCAL POLICY SUSTAINABILITY IN ROMANIA
}

\author{
Professor PhD. Ioan Talpoş, West University of Timisoara,ioan.talpos@feea.uvt.ro \\ Lecturer PhD Candidate Cosmin Enache, West University of Timisoara, \\ cosmin.enache@feaa.uvt.ro
}

\begin{abstract}
The paper is focused on aspects regarding fiscal policy sustainability in Romania. Analyzing the theoretical foundations of fiscal policy sustainability it could be identified a methodology for econometric tests to be carried out and to put forward de facto public debt longrun situation at the country level. In this direction, we carried out stationarity tests for the stock of the gross public debt and cointegration tests for the public revenues end public expenditures flows for the case of Romania.
\end{abstract}

Keywords: fiscal policy, sustainability, stationarity tests, cointegration tests

JEL codes: H20, H63, C22, C32

\section{INTRODUCTION}

A lot of contemporary economies run public deficits and accumulate significant stocks of public debt, so the problem of long-term sustainability of fiscal policy is an important and actual one.

The relevance of the fiscal policy sustainability was envisaged at the beginning of the past century, after de First World War by the English lord John Maynard Keynes in his study regarding the problem of the French public debt: "the state liabilities (...) have reached an excessive proportion of national income" (Keynes, 1938).

Following this first approach, in a modern vision, the fiscal policy undertaken by the government could be defined as sustainable if it is "a policy such the ratio of debt to GNP eventually converges to its initial level" (Blachard, Chouraqui, Hagemann, Sartor, 1990).

Theoretically, a certain level of public debt could be considered acceptable if it could be absorbed by the future primary surpluses of the public budget or, in other words, if this level is equal to the present value of the future public budget balances.

In order to distinguish this complex topic of fiscal policy sustainability, we will make an exposition similar to those in the related literature (see Blachard, Chouraqui, Hagemann, Sartor, 1990; Cuddington, 1996; Afonso, 2004).

\section{THEORETICAL BACKGROUND}

The government is facing the following budgetary constraint:

$$
\mathrm{G}_{\mathrm{t}}+\left(1+\mathrm{r}_{\mathrm{t}}\right) \mathrm{B}_{\mathrm{t}-1}=\mathrm{R}_{\mathrm{t}}+\mathrm{B}_{\mathrm{t}}(1)
$$

where:

$\mathrm{G}-$ public expenditures of the period, not including the interest expenditures attached to the public debt;

B - public debt stock of the period;

$\mathrm{R}-$ public revenues of the period; 
Taking into account the fact that budgetary periods have (at least virtually) an infinite succession, we could rewrite the equation (1) for the periods $t+1, t+2, t+3, \ldots$, and we could solve the resulting equations system for $\mathrm{B}_{\mathrm{t}}$. Therefore, it could be derived the inter-temporary budgetary constraint for government authorities:

$$
B_{t}=\sum_{k=1}^{\infty} \frac{R_{t+k}-G_{t+k}}{\prod_{j=1}^{k}\left(1+r_{t+j}\right)}+\lim _{k \longrightarrow \infty} \prod_{j=1}^{k} \frac{B_{t+k}}{\left(1+r_{t+j}\right)}
$$

Supposing that the real interest rate is stationary and with a mean $r$ (as the empirical studies on this matter show very clearly, this is extremely probable), the total public expenditures $\left(E_{t}\right)$ is given by the following relation:

$$
\mathrm{E}_{\mathrm{t}}=\mathrm{G}_{\mathrm{t}}+\left(\mathrm{r}_{\mathrm{t}}-\mathrm{r}\right) \mathrm{B}_{\mathrm{t}-1}(3)
$$

In these conditions, the relation (2) becomes:

$$
B_{t}=\sum_{k=1}^{\infty} \frac{1}{(1+r)^{k}}\left(R_{t+k}-E_{t+k}\right)+\lim _{k \longrightarrow \infty} \frac{B_{t+k}}{(1+r)^{k}}
$$

The first term from the right side of relation (4) represents the present value of the future primary budgetary surpluses. If the second term of relation is zero, than the value of the public debt current stock is equal with the present value of future primary budgetary surpluses. In this case, the fiscal policy promoted by the government could be considered sustainable. Therefore, it is necessary to impose the following transversality condition:

$$
\lim _{k \rightarrow \infty} \frac{B_{t+k}}{(1+r)^{k}}=0
$$

The transversality condition in (5) forces the government authorities not to engage in Ponzigames regarding public finances ("a government engages in Ponzi finance if, after some date, it never runs a primary (non-interest) budget surplus despite having a positive stock of debt outstanding" - (Buiter, Kletzer, 1994)). In other words, this condition imposes that the present value of the public debt to converge to zero in an indefinite future.

The fiscal policy sustainability condition could be also written in rates to GDP. Therefore, we could rewrite the relation (1) as follows:

$$
\begin{gathered}
\frac{B_{t}}{Y_{t}}=\frac{\left(1+r_{t}\right)}{\left(1+y_{t}\right)} \frac{B_{t-1}}{Y_{t-1}}+\frac{G_{t}}{Y_{t}}-\frac{R_{t}}{Y_{t}}(6) \\
b_{t}=\frac{\left(1+r_{t}\right)}{\left(1+y_{t}\right)} b_{t-1}+g_{t}-q_{t}(7)
\end{gathered}
$$

where:

Y $\quad-$ GDP;

$\mathrm{y} \quad-$ real growth rate of GDP; 
b, g, q-public debt, public expenditure and respectively public revenues relative values to GDP.

Considering the real interest rate as stationary and with mean $r$ an the economic growth rate $y$, the inter-temporal budgetary constraint is given by the following relation:

$$
b_{t-1}=\sum_{k=0}^{\infty}\left(\frac{1+y}{1+r}\right)^{k+1}\left(q_{t+k}-e_{t+k}\right)+\lim _{k \rightarrow \infty} b_{t+k}\left(\frac{1+y}{1+r}\right)^{k+1}
$$

Next, to ensure that the "inherited" public debt stock is equal to indefinite flow of future budgetary surpluses, we have to impose the following condition:

$$
\lim _{k \rightarrow \infty} b_{t+k}\left(\frac{1+y}{1+r}\right)^{k+1}=0
$$

An alternative indicator of fiscal policy sustainability derived using the same conceptual and methodological framework as the one already presented is Blachard's sustainability index $\left(\mathrm{I}_{\mathrm{B}}\right)$ (Blachard, Chouraqui, Hagemann, Sartor, 1990). This index is given by the difference between the sustainable level of taxation $\left(\mathrm{t}^{*}\right)$ and the current level of taxation $(\mathrm{t})$.

$$
I_{B}=t^{*}-t(10)
$$

In their approach, the sustainable level of taxation could be determined if the expected level of public expenditures and the initial level of public debt are both known. This level of taxation will be given by the ratio of actual values of public expenditures to GDP supplemented by the difference between the ex ante interest rate and the economic growth rate, multiplied with the ratio of public debt to GDP.

The interpretation of this indicator is extremely simple: if the sustainable level of taxation exceeds the current level of taxation it is obvious that in the future is necessary an increase in global tax burden, until the sustainable level of taxation is attained. Moreover, the exact size of the necessary increase is known by the government authorities because is given by the sustainability index.

In conclusion, the fiscal policy measures regarding the budget balance and the public debt could be considered sustainable if:

- the present value of future budgetary surpluses is equal to the current stock of public debt;

- the present value of public debt approaches zero in an infinite time horizon.

\section{METHOD AND RESULTS}

The fiscal policy sustainability could be proven empirically through:

- tests for the stationarity of the first differences of public debt stock;

- tests for a first-order cointegration relation between the first differences of total public expenditures (including debt's interest) an total public revenues.

\subsection{Stationarity tests}

In order to verify the sustainability condition in (5) is sufficient to test if the time series of first differences of public debt stock is stationary (that is "if its mean and variance are constant over time and the value of covariance between two periods depends only on the distance or lag between 
two time periods and not on the actual time at which the covariance is computed" (Gujarati, 1995)). In order to do this, we used the ADF (Augmented Dickey-Fuller) stationarity test.

The time series used for the test was composed by 33 observations, representing the quarterly gross consolidated public debt stock of Romania for the period between 2000 - quarter I and 2008 quarter III. The statistical data source was the EU statistical database - Eurostat.

The results of ADF test for the first differences of public debt stock are the following:

\section{The results of ADF test for the first differences of public debt stock}

Table no. 1

Null Hypothesis: D(PDRO) has a unit root

Exogenous: Constant

Lag Length: 0 (Automatic based on SIC, MAXLAG=8)

\begin{tabular}{llcc}
\hline \hline & & t-Statistic & Prob.* $^{*}$ \\
\hline \hline Augmented Dickey-Fuller test statistic & & -6.906661 & 0.0000 \\
\hline Test critical values: & $1 \%$ level & -3.653730 & \\
& $5 \%$ level & -2.957110 & \\
& $10 \%$ level & -2.617434 &
\end{tabular}

*MacKinnon (1996) one-sided p-values.

Augmented Dickey-Fuller Test Equation

Dependent Variable: D(PDRO,2)

Method: Least Squares

Sample (adjusted): 2000Q3 2008Q2

Included observations: 32 after adjustments

$\begin{array}{crrrr}\text { Variable } & \text { Coefficient } & \text { Std. Error } & \text { t-Statistic } & \text { Prob. } \\ \text { D(PDRO(-1) }) & -1.229144 & 0.177965 & -6.906661 & 0.0000 \\ \text { C } & 299.7141 & 116.5732 & 2.571038 & 0.0153\end{array}$

R-squared

0.613909 Mean dependent var

4.765625

Adjusted R-squared

0.601040 S.D. dependent var

971.4424

S.E. of regression

613.5951 Akaike info criterion

15.73701

Sum squared resid

11294970 Schwarz criterion

15.82862

Log likelihood

-249.7921 F-statistic

47.70196

Durbin-Watson stat

1.959707 Prob(F-statistic)

0.000000

The obtained results confirm the stationarity hypothesis for the first differences of public debt stock $(\tau$ - statistic value obtained through ADF test $-6,90$ is lower than the MacKinnon critical values (-3,65, $2,96,-2,62)$ and the probability that the stationarity hypothesis not to be verified is $0 \%$. Therefore, the future evolution of Romania's public debt stock will converge to a stationary level and will not be permanently affected by eventual shocks.

\subsection{Cointegration test}

The existence of a co-integration relation between two variables proves that between these variables exists a long-term (equilibrium) relation. Therefore, even if the time series of the respective variables are non-stationary, a linear combination of these two time series could be stationary.

In order that inter-temporal budgetary constraint (4) to be satisfied, it is necessary that the variables $\mathrm{R}$ (public revenues) and $\mathrm{E}$ (public expenditures) to be cointegrated. That is, there is a relation between these variable of the following kind: 


$$
\mathrm{R}_{\mathrm{t}}=\mathrm{a}+\mathrm{bE}_{\mathrm{t}}+\mathrm{u}_{\mathrm{t}}
$$

where: $\mathrm{a}, \mathrm{b}$ - constants;

$\mathrm{u}_{\mathrm{t}}$-stochastic variable with zero mean, constant variance $\sigma^{2}$ and non-self-correlated.

In these conditions, we will test if the time series of public revenues and public expenditures (including public debt's interest) are cointegrated. The tests' results could be interpreted as follows:

- if there is not a cointegration relation between the two time series, then fiscal policy is not sustainable;

- if there is a cointegration relation between the two time series and the coefficient $b=1$, then the fiscal policy is sustainable;

- if there is a cointegration relation between the two time series and the coefficient $b<1$, then the fiscal policy is not sustainable.

For the cointegration test we used monthly data for public revenues and public expenditures from the period between January 1997 and august 2008. the source of these data is NBR.

For start, we tested if the time series of the two variables, public revenues (TVRO) and public expenditures (TCRO) are stationary or non-stationary. The results of the ADF stationarity tests for the time series of public revenues are the following: 
The results of the ADF test for the time series of public revenues

Table no. 2

Null Hypothesis: TVRO has a unit root

Exogenous: None

Lag Length: 7 (Automatic based on SIC, MAXLAG=13)

\begin{tabular}{lccc}
\hline \hline & & t-Statistic & Prob.* \\
\hline \hline Augmented Dickey-Fuller test statistic & & 2.743761 & 0.9985 \\
\hline Test critical values: & $1 \%$ level & -2.582599 & \\
& $5 \%$ level & -1.943266 & \\
& $10 \%$ level & -1.615111 & \\
\hline \hline
\end{tabular}

*MacKinnon (1996) one-sided p-values.

Augmented Dickey-Fuller Test Equation

Dependent Variable: D(TVRO)

Method: Least Squares

Sample (adjusted): 1997M09 2008M08

Included observations: 132 after adjustments

\begin{tabular}{ccccc}
\hline \hline Variable & Coefficient & Std. Error & t-Statistic & Prob. \\
\hline \hline TVRO(-1) & 0.042444 & 0.015469 & 2.743761 & 0.0070 \\
D(TVRO(-1)) & -0.929725 & 0.095252 & -9.760644 & 0.0000 \\
D(TVRO(-2)) & -0.655091 & 0.128203 & -5.109793 & 0.0000 \\
D(TVRO(-3)) & -0.214119 & 0.143670 & -1.490348 & 0.1387 \\
D(TVRO(-4)) & -0.326681 & 0.139026 & -2.349786 & 0.0204 \\
D(TVRO(-5)) & -0.249914 & 0.139654 & -1.789528 & 0.0760 \\
D(TVRO(-6)) & 0.437442 & 0.126980 & 3.444960 & 0.0008 \\
D(TVRO(-7)) & 0.393241 & 0.099770 & 3.941461 & 0.0001 \\
\hline \hline & 0.873523 & Mean dependent var & & 67.93212 \\
R-squared & 0.866383 & S.D. dependent var & & 1275.379 \\
Adjusted R-squared & 466.1981 & Akaike info criterion & & 15.18579 \\
S.E. of regression & 26950244 & Schwarz criterion & & 15.36051 \\
Sum squared resid & -994.2622 & Durbin-Watson stat & & 1.825959 \\
Log likelihood & \multicolumn{3}{c}{} \\
\hline \hline
\end{tabular}

It could be noticed that the obtained results confirm with $99.85 \%$ probability that the public revenues time series (TVRO) has a unit root. So, the time series is not stationary and it has a random walk. In other words, TVRO is not $\mathrm{I}(0)$.

We realized the same test for the first differences of the public revenues time series. The results are the following: 
Table no. 3

The results of the ADF test for the first differences of the public revenues time series

Null Hypothesis: D(TVRO) has a unit root

Exogenous: None

Lag Length: 6 (Automatic based on SIC, MAXLAG=13)

\begin{tabular}{lccc}
\hline \hline & & & \\
& & t-Statistic & Prob. ${ }^{*}$ \\
\hline \hline Augmented Dickey-Fuller test statistic & & -2.302311 & 0.0211 \\
\hline Test critical values: & $1 \%$ level & -2.582599 & \\
& $5 \%$ level & -1.943266 & \\
& $10 \%$ level & -1.615111 & \\
\hline \hline
\end{tabular}

*MacKinnon (1996) one-sided p-values.

Augmented Dickey-Fuller Test Equation

Dependent Variable: D(TVRO,2)

Method: Least Squares

Sample (adjusted): 1997M09 2008M08

Included observations: 132 after adjustments

\begin{tabular}{ccccc}
\hline \hline \multicolumn{1}{c}{ Variable } & Coefficient & Std. Error & t-Statistic & Prob. \\
\hline \hline D(TVRO(-1)) & -0.816541 & 0.354661 & -2.302311 & 0.0230 \\
D(TVRO(-1),2) & -0.956096 & 0.335401 & -2.850607 & 0.0051 \\
D(TVRO(-2),2) & -1.343111 & 0.297520 & -4.514359 & 0.0000 \\
D(TVRO(-3),2) & -1.247122 & 0.258337 & -4.827506 & 0.0000 \\
D(TVRO(-4),2) & -1.280922 & 0.211897 & -6.045024 & 0.0000 \\
D(TVRO(-5),2) & -1.235721 & 0.148742 & -8.307837 & 0.0000 \\
D(TVRO(-6),2) & -0.541724 & 0.085979 & -6.300641 & 0.0000 \\
\hline \hline R-squared & 0.952838 & Mean dependent var & & -39.68955 \\
Adjusted R-squared & 0.950574 & S.D. dependent var & & 2151.044 \\
S.E. of regression & 478.2170 & Akaike info criterion & & 15.22958 \\
Sum squared resid & 28586433 & Schwarz criterion & & 15.38245 \\
Log likelihood & -998.1522 & Durbin-Watson stat & & 1.889332 \\
\hline \hline
\end{tabular}

The obtained results show that the first differences of public revenues time series is stationary (or TVRO is I(1)).

The stationarity test for public expenditures time series are the following: 
The results of the ADF test for the time series of public expenditures

Table no. 4

Null Hypothesis: TCRO has a unit root

Exogenous: None

Lag Length: 11 (Automatic based on SIC, MAXLAG=13)

\begin{tabular}{llll}
\hline \hline & & t-Statistic & Prob.* \\
\hline \hline Augmented Dickey-Fuller test statistic & & 9.557844 & 1.0000 \\
\hline Test critical values: & $1 \%$ level & -2.583153 & \\
& $5 \%$ level & -1.943344 \\
& $10 \%$ level & -1.615062 \\
\hline \hline
\end{tabular}

*MacKinnon (1996) one-sided p-values.

Augmented Dickey-Fuller Test Equation

Dependent Variable: D(TCRO)

Method: Least Squares

Sample (adjusted): 1998M01 2008M08

Included observations: 128 after adjustments

\begin{tabular}{ccccc}
\hline \hline Variable & Coefficient & Std. Error & t-Statistic & Prob. \\
\hline \hline TCRO(-1) & 0.230732 & 0.024141 & 9.557844 & 0.0000 \\
D(TCRO(-1)) & -1.144081 & 0.082236 & -13.91219 & 0.0000 \\
D(TCRO(-2)) & -1.054927 & 0.097023 & -10.87296 & 0.0000 \\
D(TCRO(-3)) & -1.008039 & 0.102215 & -9.861985 & 0.0000 \\
D(TCRO(-4)) & -0.995971 & 0.109314 & -9.111138 & 0.0000 \\
D(TCRO(-5)) & -0.963901 & 0.116809 & -8.251914 & 0.0000 \\
D(TCRO(-6)) & -0.874732 & 0.121258 & -7.213824 & 0.0000 \\
D(TCRO(-7)) & -0.867316 & 0.117379 & -7.389056 & 0.0000 \\
D(TCRO(-8)) & -0.927077 & 0.113427 & -8.173299 & 0.0000 \\
D(TCRO(-9)) & -1.034645 & 0.107852 & -9.593193 & 0.0000 \\
D(TCRO(-10)) & -0.995152 & 0.100492 & -9.902780 & 0.0000 \\
D(TCRO(-11)) & -0.750002 & 0.078856 & -9.511042 & 0.0000 \\
\hline \hline R-squared & 0.672230 & Mean dependent var & & 81.12344 \\
Adjusted R-squared & 0.641148 & S.D. dependent var & & 1520.624 \\
S.E. of regression & 910.9179 & Akaike info criterion & & 16.55584 \\
Sum squared resid & 96253478 & Schwarz criterion & 16.82322 \\
Log likelihood & -1047.574 & Durbin-Watson stat & 2.110486 \\
\hline \hline
\end{tabular}

As in the public revenues case, the obtained results confirm with a $100 \%$ probability that the public expenditure time series (TCRO) has a unit root, which means that the time series is not stationary and is a random walk. In other words, TVCO is not I(0).

The same test was applied for the first differences of the public expenditures time series and the obtained results were the following: 
The results of the ADF test for the first differences of the public expediture time series

Null Hypothesis: D(TCRO) has a unit root

Exogenous: None

Lag Length: 4 (Fixed)

\begin{tabular}{lccc}
\hline \hline & & t-Statistic & Prob.* \\
\hline \hline Augmented Dickey-Fuller test statistic & & -8.961715 & 0.0000 \\
\hline Test critical values: & $1 \%$ level & -2.582334 & \\
& $5 \%$ level & -1.943229 \\
& $10 \%$ level & -1.615134 \\
\hline \hline
\end{tabular}

*MacKinnon (1996) one-sided p-values.

Augmented Dickey-Fuller Test Equation

Dependent Variable: D(TCRO,2)

Method: Least Squares

Sample (adjusted): 1997M07 2008M08

Included observations: 134 after adjustments

\begin{tabular}{|c|c|c|c|c|}
\hline Variable & Coefficient & Std. Error & $\mathrm{t}$-Statistic & Prob. \\
\hline $\mathrm{D}(\mathrm{TCRO}(-1))$ & -2.970182 & 0.331430 & -8.961715 & 0.0000 \\
\hline $\mathrm{D}(\mathrm{TCRO}(-1), 2)$ & 1.381164 & 0.283796 & 4.866744 & 0.0000 \\
\hline $\mathrm{D}(\mathrm{TCRO}(-2), 2)$ & 0.961567 & 0.222951 & 4.312907 & 0.0000 \\
\hline $\mathrm{D}(\mathrm{TCRO}(-3), 2)$ & 0.553170 & 0.158500 & 3.490036 & 0.0007 \\
\hline $\mathrm{D}(\mathrm{TCRO}(-4), 2)$ & 0.205139 & 0.086810 & 2.363071 & 0.0196 \\
\hline R-squared & 0.740343 & Mean dependent var & & -8.989627 \\
\hline Adjusted R-squared & 0.732292 & S.D. dependent var & & 2468.435 \\
\hline S.E. of regression & 1277.182 & Akaike info criterion & & 17.17930 \\
\hline Sum squared resid & $2.10 \mathrm{E}+08$ & Schwarz criterion & & 17.28743 \\
\hline Log likelihood & -1146.013 & Durbin-Watson stat & & 1.973635 \\
\hline
\end{tabular}

The obtained results confirm that first differences of the public expenditures time series is stationary (or TCRO is I(1)).

Both public revenues time series and public expenditures time series are I(1), so we could apply the cointegration test. The obtained results were the following: 


\section{The results of the cointegration test}

Table no. 6

Sample (adjusted): 1997M06 2008M08

Included observations: 135 after adjustments

Trend assumption: No deterministic trend

Series: TCRO TVRO

Lags interval (in first differences): 1 to 4

Unrestricted Cointegration Rank Test (Trace)

\begin{tabular}{ccccc}
\hline \hline $\begin{array}{c}\text { Hypothesized } \\
\text { No. of CE(s) }\end{array}$ & Eigenvalue & $\begin{array}{c}\text { Trace } \\
\text { Statistic }\end{array}$ & $\begin{array}{c}0.05 \\
\text { Critical Value }\end{array}$ & Prob.** \\
\hline \hline None * & 0.228785 & 53.22739 & 12.32090 & 0.0000 \\
At most $1 *$ & 0.125837 & 18.15599 & 4.129906 & 0.0000 \\
\hline \hline
\end{tabular}

Trace test indicates 2 cointegrating eqn(s) at the 0.05 level

* denotes rejection of the hypothesis at the 0.05 level

**MacKinnon-Haug-Michelis (1999) p-values

Unrestricted Cointegration Rank Test (Maximum Eigenvalue)

\begin{tabular}{ccccc}
\hline \hline $\begin{array}{c}\text { Hypothesized } \\
\text { No. of CE(s) }\end{array}$ & Eigenvalue & $\begin{array}{c}\text { Max-Eigen } \\
\text { Statistic }\end{array}$ & $\begin{array}{c}0.05 \\
\text { Critical Value }\end{array}$ & Prob.** \\
\hline \hline None & 0.228785 & 35.07140 & 11.22480 & 0.0000 \\
At most $1 *$ & 0.125837 & 18.15599 & 4.129906 & 0.0000 \\
\hline \hline
\end{tabular}

Max-eigenvalue test indicates 2 cointegrating eqn(s) at the 0.05 level

* denotes rejection of the hypothesis at the 0.05 level

**MacKinnon-Haug-Michelis (1999) p-values

Unrestricted Cointegrating Coefficients (normalized by $b^{\prime *} \mathrm{~S} 11 * \mathrm{~b}=\mathrm{I}$ ):

$\begin{array}{cc}\text { TCRO } & \text { TVRO } \\ -0.001635 & 0.001615 \\ 0.001442 & -0.001757\end{array}$

Unrestricted Adjustment Coefficients (alpha):

\begin{tabular}{crl}
\hline \hline $\mathrm{D}($ TCRO $)$ & 276.0634 & -344.5471 \\
$\mathrm{D}($ TVRO) & -136.6627 & -157.3716 \\
\hline \\
\hline
\end{tabular}

Normalized cointegrating coefficients (standard error in parentheses)
TCRO
TVRO
1.000000
$-0.987676$ 
Adjustment coefficients (standard error in parentheses)

$\mathrm{D}$ (TCRO) $\quad-0.451310$

(0.15956)

$\mathrm{D}(\mathrm{TVRO}) \quad 0.223417$

(0.07423)

The obtained result show with a $100 \%$ probability that there is at least two cointegration relations between the two time series, and the cointegration equation is the following:

$$
\mathrm{TCRO}=0,9877 \mathrm{TCRO}+\mathrm{u}
$$

Because the coefficient $b$ is less than $1(b=0,9877)$, but very close to 1 , we could conclude that in Romania, if the determinants of the public revenues and public expenditures remain unchanged, the public debt will not have a divergent evolution and the fiscal policy will be sustainable in the long run.

\section{CONCLUSIONS}

Since the beginning of the transition process, redefining the public authorities' role in the economy and society necessitated significant institutional and structural reforms. In these conditions, our country government authorities were and still are facing a strong constraint: to satisfy increasing public needs with limited fiscal resources, due to a small tax base.

This paper was not focused on short-term management of a negative budget balance. Instead, it was trying to apply an appropriate methodology in order to reveal the cumulative long-term effects of the government authorities' decisions regarding the budget balance and the public debt.

The fiscal policy sustainability was verified through two methods: a stationarity test for the public debt stock time series and a Johanssen cointegration test for the public revenues and public expenditures time series.

The ADF stationarity test for the quarterly public debt time series revealed that Romania's fiscal policy is sustainable in the long-run.

Applying the Johanssen cointegration test for the monthly public revenues and public expenditures time series we find, with a probability of almost $99 \%$, that there is at least two cointegration relations between the two time series. Because the resulted coefficient $b$ in the cointegration equation is less than 1 , but very close to 1 , we conclude that in Romania, if the determinants of the public revenues and public expenditures remain unchanged, the public debt will not have a divergent evolution and the fiscal policy will be sustainable in the long run.

\section{References}

1. Afonso A. (2005) - Fiscal Sustainability: the Unpleasant European Case, FinanzArchiv: Public Finance Analysis, Mohr Siebeck, Tübingen, vol. 61(1), pages 19-, March.

2. Blanchard O., Chouraqui J-C., Hagemann R. P., Sartor N. (1990) - The Sustanability of Fiscal Policy: New Answers to an Old Question, OECD Economic Studies, no. 15

3. Buiter W. H., Kletzer K. M (1994).- Ponzi Finance, Government Solvency and the Redundancy or Usefulness of Public Debt, Cowles Foundation Discussion Paper, no. 1070

4. Cuddington J. T.(1996) - Analysing the Sustainability of Fiscal Deficits in Developing Countries, World Bank Policy Research Working Paper No. 1784.

5. Gujarati D. N.(1995) - Basic Econometrics, $3^{\text {rd }}$ ed., McGraw-Hill Book Co.

6. Keynes J. M.(1938) - A Tract of Monetary Reform, cited in Antonio Afonso - Fiscal Sustainability: the Unpleasant European Case, 2004. 